\title{
Systematic review: Occupational stress of health professionals in times of pandemic [Revisión Sistemática: Estrés laboral de los profesionales de la salud en tiempos de pandemia]
}

\author{
Eunice Parco-Fernández (iD), Abigail Joaquin-Apaza *,(D), Mónica Cárdenas- \\ Vásquez (iD.
}

Instituto Nacional de Enfermedades Neoplásicas, Perú.

*abyioaquina@hotmail.com

Received: 02 January 2022; Accepted: 20 January 2022; Published: 29 January 2022

\section{Resumen}

El estrés laboral en los profesionales de la salud se ha incrementado los dos últimos años por la presencia del SARS-COV2, siendo de impacto a nivel mundial. Objetivo: Analizar el desarrollo de las evidencias científicas sobre el estrés laboral en tiempos de pandemia dirigido a los profesionales de la salud. Metodología: se realizó una búsqueda bibliográfica de cuatro bases de datos, se incluyeron estudios en idiomas inglés, español y portugués publicados en revistas indexadas con texto completo. Se realizó un análisis crítico de cada uno de los artículos y se plasmó en una matriz para ordenar la información y categorizarlos. Los resultados muestran que los factores desencadenantes del estrés laboral están relacionados sobrecarga laboral, cansancio, temor y miedo que perciben los profesionales de la salud ante la situación de pandemia. Sin embargo, existe factores protectores para el estrés laboral y políticas preventivas y ocupacionales frente al estrés laboral que pueden paliar esta situación. Conclusiones: Los niveles altos de estrés laboral en los profesionales sanitarios ocasiona daños físicos y psicológicos, los autores coinciden en tomar acciones preventivas para mitigar el impacto en la salud metal de los trabajadores.

Palabras clave: Estrés laboral, profesionales de la salud, pandemia, revisión sistemática.

\begin{abstract}
Work stress in health professionals has increased in the last two years due to the presence of SARS-COV2, being of worldwide impact. Objective: To analyze the development of scientific evidence on work stress in times of pandemic directed to health professionals. Methodology: a bibliographic search of four databases was carried out, including studies in English, Spanish and Portuguese published in full-text indexed journals. A critical analysis was made of each of the articles and a matrix was used to order the information and categorize them. The results show that the triggers of occupational stress are related to work overload, fatigue, fear and fear perceived by health professionals in the pandemic situation. However, there are protective factors for work stress and preventive and occupational policies against work stress that can alleviate this situation. Conclusions: High levels of occupational stress in health professionals cause physical and psychological damage, the authors agree in taking preventive actions to mitigate the impact on the metal health of workers.
\end{abstract}

Keywords: Occupational stress, health professionals, pandemic, systematic review. 


\section{GHM \\ Journal of Global Health and Medicine}

Vol. 6, $\mathrm{N}^{\circ} 1,2022$

Copyright @ 2022, CINCADER.

ISSN 2523-9511

DOI: https://doi.org/10.32829/ghmj.v6i1.158

\section{Introduction}

Nowadays stress is a common topic in research, being work stress the one that affects workers generating psychological, physiological and occupational damage (OIT, 2016), under the context of the SARS COV-2 pandemic, work stress has been increasing over time (CDC, 2021). The World Health Organization (WHO, 2019) reported the first case of pneumonia of unknown cause in China, which occurred in the city of Wuhan and already in January 2020 the WHO declared COVID-19 as a Public Health Emergency of International Concern (PHEI), and in March of the same year it was classified as a pandemic. From that moment on, the spread of the SARS-CoV2 coronavirus has not ceased to experience an enormous growth, first spreading rapidly through the rest of the provinces in China and later to the rest of the continents, producing millions of daily infections and numerous deaths, reaching the point of collapsing health services (PAHO, 2019).

Mental health, according to $\mathrm{WHO}$, is a state in which each person understands his or her own abilities to cope with daily stress and to know how to work effectively and productively (OlivaYarleque \& Chávarry-Ysla, 2021). In this sense, stress is defined as "a set of physiological reactions that prepare the organism for action". However, Sotillo mentions that occupational stress is a set of phenomena that manifest themselves in the organism and health of the worker with the participation of harmful stressors derived directly from work (Munawar \& Riaz, 2021).

On the other hand, there are 2 types of occupational stress such as acute stress that appears punctually and its effects are moderate, then we have the type of chronic stress, considered dangerous, prolonged exposure to occupational stress due to a bad work environment, harassment at work or an unstable work situation, having consequences on the worker in physical and mental forms Today the mental health of the world population is affected by the pandemic, the numbers of contagion and deaths have increased rapidly, affecting the quality of life of human beings (Lozano-Vargas, 2020).

Likewise, health care workers who are on the front line are exposed to and in direct contact with confirmed or suspected cases of COVID-19, being a highly vulnerable population to contract health problems, in whom there is also evidence of episodes of stress, fear, anxiety, depressive states, among other situations of nervous disorders that affect the ability to resolve and make decisions in the quality of service provided to the patient (Ozamiz-Etxebarria et al., 2020); (Ferreira et al., 2020).

It should be noted that emotional intelligence developed through professional training and job performance is an important tool for decision making in critical situations; however, with this pandemic, in some health professionals it has been weakened, especially in nursing staff due to vulnerability to occupational hazards and a high burden of emotional stress related to their job performance (Oliva-Yarleque \& Chávarry-Ysla, 2021).

Several studies have shown the psychological impact on the healthcare worker working in the fight against the SARS pandemic COV 2, thus, studies conducted in India by (William et al., 2020), evaluated the prevalence of stress, anxiety and depression among healthcare workers who are directly involved in the triage, diagnosis and treatment of patients with this disease; concluding that the prevalence of stress, depressive symptoms and anxiety among health professionals is comparable with other countries; they also found that the female sex was more likely to suffer from psychological problems compared to the male sex; this last finding, coincides with that reported by (Chávez et al., 2020), who reported that health care workers who are struggling with this disease and workers in Wuhan reported more severe degrees of all measures of mental health symptoms compared to other health care workers. Likewise, De los Santos et al. report that among health professionals, nurses suffer the highest degree of anxiety and stress from caring for and treating patients with the COVID-19 virus (De los Santos \& Labrague, 2020). 
Vol. 6, $\mathrm{N}^{\circ} 1,2022$

Copyright (c) 2022, CINCADER.

ISSN 2523-9511

DOI: https://doi.org/10.32829/ghmj.v6i1.158

On the other hand, Monterrosa-Castro et al., (2020) argue that 7 out of 10 general practitioners assessed presented manifestations of anxiety or work stress, while 4 presented symptoms of fear of COVID-19. It also mentions that the factors that predispose to fear, anxiety and stress are related to the irresponsibility of the citizen and the lack of hygiene measures, causing an increase in the deterioration of the mental health of the population and health workers. At the national level, Peru was one of the first countries in Latin America to declare a state of emergency, being one of the most affected in the health sector collapsing due to the presence of COVID-19 and as a product of the pandemic, health professionals were also affected with occupational stress dealing with various problems; according to the study of Munawar \& Riaz (2021), mentions that overwork, work under pressure, proximity to death, suffering, disorganization of functions, organizational climate, discontinuous schedules, not being able to express claims, unstable labor contracts, lack of empathy among workers, lack of assertive communication among the health team harm the living conditions of the professional and their environment, in addition, work performance is decreasing the quality of services in patient care, being reflected in production.

Finally, Marquina-Lujan \& Adriazola, (2020), concluded that health personnel are predisposed to high levels of stress manifested by their physical reactions such as: altered appetite, sleep, exhaustion, and affecting their psychological health and this has repercussions on their adequate performance in the professional and personal sphere. In this context and considering the need to investigate the approach to the psychological impact of health professionals in the face of the SARS VOC-2 pandemic, this study aims to know the current global situation of occupational stress, identifying in each article the stressors present, having the possibility of contributing with strategies to cover the existing gaps in mental health and help cushion the psychological impact of health professionals now and in the near future.

\section{Materials and methods}

A review was made of indexed articles whose central theme is Work stress of health professionals in times of pandemic. Having used the "AND" algorithm and the variables were (work stress) AND (pandemic) (English), (estresse no trabalho) AND (pandemia) (Portuguese). The inclusion criteria were: scientific articles from 2020 to 2021, the time when the SARS COV-2 pandemic is triggered, it has a methodology with scientific rigor, it also answers the research question in this study. Based on the information obtained, a bibliographic review of a total of published articles was carried out.

Table 1: Database and phases developed to obtain information.

\begin{tabular}{|l|c|c|c|c|}
\hline Database & 1. Identification & 2. Selection & 3. Eligibility & 4. Inclusion \\
\hline Scielo & 70 & 12 & 7 & 6 \\
\hline Lilacs & 44 & 41 & 41 & 2 \\
\hline ScienceDirect & 17091 & 3887 & 983 & 4 \\
\hline PubMed & 2179 & 1974 & 1274 & 7 \\
\hline Total & 19384 & 5914 & 2305 & 19 \\
\hline
\end{tabular}




\section{GHM \\ Journal of Global Health \\ and Medicine}

Vol. 6, $\mathrm{N}^{\circ}$ 1, 2022

Copyright (C) 2022, CINCADER.

ISSN 2523-9511

DOI: https://doi.org/10.32829/ghmj.v6i1.158

\section{Results}

Table 2. Systematic review: occupational stress of health professionals in times of pandemic 2020-2021.

\begin{tabular}{|c|c|c|c|c|c|}
\hline Authors & Title & eywords & $\begin{array}{l}\text { Instrument } \\
s \text { and/or } \\
\text { techniques }\end{array}$ & $\begin{array}{c}\text { Dimension } \\
\text { s/ } \\
\text { categories }\end{array}$ & $\begin{array}{c}\text { Results } \\
\text { Conclusions }\end{array}$ \\
\hline $\begin{array}{l}\text { Ramachandr } \\
\text { an, A., } \\
\text { Savrimalai, } \\
\text { C., Kattula, } \\
\text { D., } \\
\text { Thavarajah, } \\
\text { R., \& } \\
\text { Arunachalam } \\
\text {, A. (2020). }\end{array}$ & $\begin{array}{l}\text { Stress levels } \\
\text { of Indian } \\
\text { Endodontists } \\
\text { during the } \\
\text { COVID-19 } \\
\text { pandemic. }\end{array}$ & $\begin{array}{l}\text { - } \text {-Stress } \\
\text { - India } \\
\text { - Distress } \\
\text { - Endodon } \\
\quad \text { tists } \\
\text { - Aerosol } \\
\text { - Covid-19 } \\
\text { - Perceptio } \\
\quad \text { n. }\end{array}$ & $\begin{array}{l}\text { Closed } \\
\text { survey } \\
\text { Sampling } \\
\text { technique }\end{array}$ & $\begin{array}{l}\text { - Demograph } \\
\text { ics and } \\
\text { characteristic } \\
\text { s of the study } \\
\text { population } \\
\text { and their } \\
\text { mental health } \\
\text { indicators of } \\
\text { endodontists. }\end{array}$ & $\begin{array}{l}\text { The professionals in this study experience } \\
\text { work stress due to the COVID-19 } \\
\text { pandemic, with a number of professionals } \\
\text { in the process of learning, in addition, } \\
\text { young women are at greater risk of work } \\
\text { stress, if immediate attention is given, the } \\
\text { stress of the professionals could be } \\
\text { reduced. The importance of preparing } \\
\text { sterilization and disinfection protocols and } \\
\text { training would reduce worker stress. }\end{array}$ \\
\hline $\begin{array}{l}\text { Rodrigues, } \\
\text { L., Coelho de } \\
\text { Oliveira, L., \& } \\
\text { França } \\
\text { Dourado, M. } \\
\text { (2020). }\end{array}$ & $\begin{array}{l}\text { Empathy, } \\
\text { depression, } \\
\text { anxiety and } \\
\text { stress in } \\
\text { Brazilian } \\
\text { health } \\
\text { professionals } \\
\text {. }\end{array}$ & $\begin{array}{l}\text { Anxiety } \\
\text { Depression } \\
\text { Stress } \\
\text { Empathy } \\
\text { Health } \\
\text { profession } \\
\text { als. }\end{array}$ & $\begin{array}{l}\text { Self- } \\
\text { assessmen } \\
\mathrm{t} \\
\text { instrument. }\end{array}$ & $\begin{array}{l}\text { Prevalence } \\
\text { of stress } \\
\text { Correlation } \\
\text { between } \\
\text { mental } \\
\text { health and } \\
\text { empathy }\end{array}$ & $\begin{array}{l}\text { Stress when present in health care } \\
\text { workers are the following symptoms: } \\
\text { alertness, endurance, near exhaustion, } \\
\text { and burnout. } \\
\text { The article has some limitations because } \\
\text { there was no balance between female and } \\
\text { male participants, nor between the number } \\
\text { of participants. It would be recommended } \\
\text { that in subsequent studies the number of } \\
\text { participants be increased. }\end{array}$ \\
\hline $\begin{array}{l}\text { Zhan, Y., } \\
\text { Shuangma, } \\
\text { Xiangdongjia } \\
\text { n, Yingjuan, } \\
\text { C. \& } \\
\begin{array}{l}\text { Xiangqiao Z. } \\
(2020) .\end{array}\end{array}$ & $\begin{array}{l}\text { The current } \\
\text { situation and } \\
\text { factors } \\
\text { influencing } \\
\text { job stress } \\
\text { among } \\
\text { frontline } \\
\text { nurses } \\
\text { helping in } \\
\text { Wuhan to } \\
\text { combat } \\
\text { COVID-19. }\end{array}$ & $\begin{array}{l}\text { COVID-19 } \\
\text { Across- } \\
\text { sectional } \\
\text { survey } \\
\text { Epidemic } \\
\text { Job Stress } \\
\text { Nurses }\end{array}$ & ire si & $\begin{array}{l}\text { General } \\
\text { demographi } \\
c \\
\text { information. } \\
\text { Application } \\
\text { of the work } \\
\text { stressors } \\
\text { scale }\end{array}$ & $\begin{array}{l}\text { Nurses have an increased responsibility } \\
\text { due to the workload not only with the } \\
\text { patient, the lack of strengthening the } \\
\text { knowledge against COVID-19, first line } \\
\text { nurses have an increased work stress } \\
\text { being higher in specialty areas, with a } \\
\text { moderate level, working hours influence } \\
\text { this result, since the beginning of the first } \\
\text { case in Wuhan, the lack of nursing staff } \\
\text { caused the work overload; the scheduling } \\
\text { of night shifts increased stress in nursing } \\
\text { staff. }\end{array}$ \\
\hline $\begin{array}{l}\text { Tengilimoğlu, } \\
\text { T., Aysu, Z., } \\
\text { Nurperihan, } \\
\text { T., Oguz, I., \& } \\
\text { Tengilimoglu, } \\
\text { O. (2021). }\end{array}$ & $\begin{array}{l}\text { Impacts of } \\
\text { the COVID- } \\
19 \text { pandemic } \\
\text { period on } \\
\text { depression, } \\
\text { anxiety and } \\
\text { stress levels } \\
\text { of healthcare }\end{array}$ & $\begin{array}{l}\text { Anxiety } \\
\text { COVID-19 } \\
\text { Depression } \\
\text { Health care } \\
\text { worker } \\
\text { Pandemic } \\
\text { Stress }\end{array}$ & $\begin{array}{l}\text { Depression } \\
\text {, Anxiety } \\
\text { and Stress } \\
\text { Scale } \\
\text { (DASS-21). }\end{array}$ & $\begin{array}{l}\text { Depression, } \\
\text { Anxiety and } \\
\text { Stress } \\
\text { Scale } \\
\text { (DASS-21) }\end{array}$ & $\begin{array}{l}\text { The main cause of anxiety and stress } \\
\text { among health workers is the fear ( } 86.9 \%) \\
\text { of contaminating their families of COVID- } \\
19 \text {, in addition, the levels of depression, } \\
\text { anxiety and stress of workers are higher in } \\
\text { male gender, the work areas with high } \\
\text { levels of stress were internal services, } \\
\text { emergency and COVID-19 area. }\end{array}$ \\
\hline
\end{tabular}


Vol. 6, $\mathrm{N}^{\circ} 1,2022$

Copyright @ 2022 , CINCADER.

ISSN 2523-9511

DOI: https://doi.org/10.32829/ghmj.v6i1.158

\begin{tabular}{|c|c|c|c|c|c|}
\hline & $\begin{array}{l}\text { employees in } \\
\text { Turkey. }\end{array}$ & & & & $\begin{array}{l}\text { To reduce the risks, they suggest } \\
\text { minimizing the risks, with the development } \\
\text { of plans for the management of } \\
\text { occupational stress of health } \\
\text { professionals, in addition, mandatory } \\
\text { referral to mental health services. }\end{array}$ \\
\hline $\begin{array}{l}\text { Orrù, G., } \\
\text { Marzetti, F., } \\
\text { Conversano, } \\
\text { C., } \\
\text { Vagheggini, } \\
\text { G., Miccoli, } \\
\text { M., Ciacchini, } \\
\text { R., Panait, } \\
\text { E., \& } \\
\text { Gemignani, } \\
\text { A. (2021). }\end{array}$ & $\begin{array}{l}\text { Secondary } \\
\text { traumatic } \\
\text { stress and } \\
\text { burnout in } \\
\text { health care } \\
\text { workers } \\
\text { during the } \\
\text { COVID-19 } \\
\text { outbreak. }\end{array}$ & $\begin{array}{l}\text { COVID-19 } \\
\text { Health care } \\
\text { worker } \\
\text { burnout. } \\
\text { Secondary } \\
\text { traumatic } \\
\text { stress. }\end{array}$ & $\begin{array}{l}\text { Secondary } \\
\text { Traumatic } \\
\text { Stress } \\
\text { Scale } \\
\text { (STSS), } \\
\text { the } \\
\text { Perceived } \\
\text { Stress } \\
\text { Scale } \\
\text { (PSS) and } \\
\text { the } \\
\text { Maslach } \\
\text { Burnout } \\
\text { Inventory } \\
\text { Human } \\
\text { Service } \\
\text { Survey } \\
\text { (MBI-HSS). }\end{array}$ & $\begin{array}{l}\text { The degree } \\
\text { of STS, } \\
\text { perceived } \\
\text { stress and } \\
\text { burnout was } \\
\text { assessed } \\
\text { using the } \\
\text { Secondary } \\
\text { Traumatic } \\
\text { Stress } \\
\text { Scale } \\
\text { (STSS), the } \\
\text { Perceived } \\
\text { Stress } \\
\text { Scale (PSS) } \\
\text { and the } \\
\text { Maslach } \\
\text { Burnout } \\
\text { Inventory } \\
\text { Human } \\
\text { Service } \\
\text { Survey } \\
\text { (MBI-HSS), } \\
\text { respectively }\end{array}$ & $\begin{array}{l}\text { They performed a multiple regression } \\
\text { analysis, identifying risk and protective } \\
\text { factors for secondary traumatic stress, } \\
\text { there were } 184 \text { surveys, presented } \\
\text { symptoms }(41.3 \%) \text {, emotional exhaustion } \\
\text { (56.0\%) and depersonalization ( } 48.9 \%) \text {; } \\
\text { the prevalence of cases was } 47.5 \% \text { in } \\
\text { front-line professionals, and those from } \\
\text { other non-COVID- } 19 \text { units was } 30.3 \% \text {; } \\
\text { exposed to death was } 67.1 \% \text { and those } \\
\text { who were not exposed was } 32.9 \% \text {. In } \\
\text { stepwise multiple regression analysis, } \\
\text { perceived stress, emotional exhaustion } \\
\text { and exposure to death of patients } \\
\text { remained significant predictors. }\end{array}$ \\
\hline $\begin{array}{l}\text { Cirami, L., } \\
\text { Córdoba, E., } \\
\text { \& Ferrari, L. } \\
(2020) \text {. }\end{array}$ & $\begin{array}{l}\text { Coping } \\
\text { strategies of } \\
\text { occupational } \\
\text { stress in } \\
\text { health care } \\
\text { workers and } \\
\text { reflections on } \\
\text { organizationa } \\
\text { I } \\
\text { transformatio } \\
\text { ns since the } \\
\text { COVID-19 } \\
\text { pandemic. }\end{array}$ & $\begin{array}{l}\text { Pandemic, } \\
\text { health } \\
\text { workers, } \\
\text { occupatio } \\
\text { nal stress }\end{array}$ & $\begin{array}{l}\text { These were } \\
\text { the EEPP, } \\
\text { the COPE- } \\
28 \text {, the } \\
\text { CEMTAL } \\
\text { symptomat } \\
\text { ology } \\
\text { subscale } \\
\text { and a } \\
\text { sociodemo } \\
\text { graphic } \\
\text { questionnai } \\
\text { re. }\end{array}$ & $\begin{array}{l}\text {-Stress } \\
\text { coping } \\
\text { strategies. } \\
\text {-The } \\
\text { relationship } \\
\text { of these } \\
\text { coping } \\
\text { strategies to } \\
\text { perceived } \\
\text { stress levels } \\
\text { and } \\
\text { symptomat } \\
\text { ology. }\end{array}$ & $\begin{array}{l}\text { The present study was conformed by } \\
\text { health personnel demonstrating } 3 \text { modes } \\
\text { of coping to stress and they are: } \\
\text { Avoidance, Approaching and Emotional, } \\
\text { showing higher rates of positive } \\
\text { relationships between Avoidance Coping } \\
\text { with perceived stress and } \\
\text { symptomatology. } \\
\text { We identified as the work overload and the } \\
\text { inability to fulfill the tasks in the proposed } \\
\text { time giving also to the lack of interpersonal } \\
\text { relationships in their workplace and } \\
\text { personal relationships themselves facing } \\
\text { in this pandemic which leads to place to } \\
\text { develop stress. }\end{array}$ \\
\hline $\begin{array}{l}\text { Franco, J. A. } \\
\text { F., \& Levi, P. }\end{array}$ & $\begin{array}{l}\text { Feelings, } \\
\text { stress and } \\
\text { coping }\end{array}$ & $\begin{array}{l}\text { Pandemic, } \\
\text { health } \\
\text { workers, }\end{array}$ & $\begin{array}{l}\text { Questionna } \\
\text { ire derived } \\
\text { and }\end{array}$ & $\begin{array}{l}\text {-Stress } \\
\text { reducing } \\
\text { factors }\end{array}$ & $\begin{array}{l}\text { The priority of the humanistic feeling and } \\
\text { the professional duty for these nurses was } \\
\text { evidenced, being mostly young and with }\end{array}$ \\
\hline
\end{tabular}


Vol. 6, $\mathrm{N}^{\circ}$ 1, 2022

Copyright @ 2022 , CINCADER.

ISSN 2523-9511

DOI: https://doi.org/10.32829/ghmj.v6i1.158

\begin{tabular}{|c|c|c|c|c|c|}
\hline $\begin{array}{l}\text { de los A. } \\
(2020) .\end{array}$ & $\begin{array}{l}\text { strategies of } \\
\text { nurses facing } \\
\text { COVID-19 in } \\
\text { Guayaquil }\end{array}$ & $\begin{array}{l}\text { occupation } \\
\text { al stress } \\
\text { Psychologi } \\
\text { cal stress, } \\
\text { Nurses, } \\
\text { Coronaviru } \\
\text { s, } \\
\text { Pandemic. }\end{array}$ & $\begin{array}{l}\text { adapted } \\
\text { from the } \\
\text { "MERS- } \\
\text { CoV staff } \\
\text { questionnai } \\
\text { re" by } \\
\text { Khalid et al. }\end{array}$ & $\begin{array}{l}\text {-Coping } \\
\text { strategies }\end{array}$ & $\begin{array}{l}\text { less than three years of professional } \\
\text { practice and the stress of the arduous day- } \\
\text { to-day work to have a safe care and thus } \\
\text { maintain strategies to cope with this } \\
\text { difficult experience during the pandemic. } \\
\text { Health services and society should be } \\
\text { more consistent in raising pandemic } \\
\text { awareness to avoid nurse burnout and } \\
\text { attrition. }\end{array}$ \\
\hline $\begin{array}{l}\text { Kuo, F.L., Yan } \\
\text { P-H., Hsu H-T } \\
\text { Su C-Y., Che } \\
\text { C-H., Yeh, Y-- } \\
\text { Wu, Y-H. } \\
\text { Chen, L-C } \\
(2020) .\end{array}$ & $\begin{array}{l}\text { Survey of } \\
\text { perceived } \\
\text { job stress } \\
\text { and its } \\
\text { influencing } \\
\text { factors } \\
\text { among } \\
\text { hospital staff } \\
\text { during the } \\
\text { COVID-19 } \\
\text { pandemic in } \\
\text { Taiwan. }\end{array}$ & $\begin{array}{l}\text { Coranoviru } \\
\text { s } \\
\text { Health } \\
\text { personnel } \\
\text { Stress }\end{array}$ & $\begin{array}{l}\text { Structured } \\
\text { web-based } \\
\text { questionnai } \\
\text { re. }\end{array}$ & $\begin{array}{l}\text { - } \\
\text { Occupation } \\
\text { al stress. } \\
\text {-Influencing } \\
\text { factors } \\
\text { among } \\
\text { health } \\
\text { personnel in } \\
\text { the face of } \\
\text { the } \\
\text { pandemic. }\end{array}$ & $\begin{array}{l}\text { As a result, the main stressor for hospital } \\
\text { staff was discomfort caused by protective } \\
\text { equipment and patient care overload } \\
\text { during the COVID-19 pandemic. } \\
\text { Health care workers being in a high stress } \\
\text { occupation, it is concluded that they should } \\
\text { be evaluated and monitored regularly and } \\
\text { provided with psychological counseling } \\
\text { and stress relief measures during the } \\
\text { pandemic. }\end{array}$ \\
\hline $\begin{array}{l}\text { Magnavita, } \\
\text { N., Soave, } \\
\text { P.M., } \\
\text { Ricciardi, W. } \\
\& \quad \text { Antonelli, } \\
\text { M. (2020). }\end{array}$ & $\begin{array}{l}\text { Occupational } \\
\text { stress and } \\
\text { mental } \\
\text { health } \\
\text { among } \\
\text { anesthesiolo } \\
\text { gists during } \\
\text { the COVID- } \\
19 \\
\text { pandemic. }\end{array}$ & $\begin{array}{l}\text { SARS- } \\
\text { CoV-2 } \\
\text { Anxiety } \\
\text { Depression } \\
\text { Emergency } \\
\text { Health care } \\
\text { workers } \\
\text { Infectious } \\
\text { disease } \\
\text { Insomnia } \\
\text { Sleep. }\end{array}$ & $\begin{array}{l}\text { Cuestionari } \\
\text { o Effort } \\
\text { Reward } \\
\text { Imbalance } \\
\text { (ERI) el } \\
\text { insomnio } \\
\text { con El } \\
\text { Sleep } \\
\text { Condition } \\
\text { Indicator } \\
\text { (SCI) }\end{array}$ & $\begin{array}{l}\text {-Levels of } \\
\text { occupationa } \\
\text { I stress. } \\
\text {-Levels of } \\
\text { organizatio } \\
\text { nal justice }\end{array}$ & $\begin{array}{l}\text { The workers reported an increased } \\
\text { workload, most of them being very } \\
\text { monotonous, which reduced their free time } \\
\text { for physical activity and meditation. } \\
\text { Therefore the occupational stress } \\
\text { evaluations had a high result in } \\
\text { anesthesiologists. } \\
\text { Organizational justice indicated that the } \\
\text { workers perceived a low capacity to } \\
\text { influence and modify the outcome of the } \\
\text { procedures and expressed doubts about } \\
\text { the reliability and explanations about the } \\
\text { ongoing pandemic. }\end{array}$ \\
\hline $\begin{array}{l}\text { Said, R. \& El- } \\
\text { Shafei, } \quad \text { D. } \\
\text { (2020). }\end{array}$ & $\begin{array}{l}\text { Occupational } \\
\text { stress, job } \\
\text { satisfaction } \\
\text { and intention } \\
\text { to leave: } \\
\text { nurses } \\
\text { working on } \\
\text { the frontline } \\
\text { during the } \\
\text { COVID-19 } \\
\text { pandemic in } \\
\text { Zagazig City, } \\
\text { Egypt }\end{array}$ & $\begin{array}{l}\text { COVID-19 } \\
\text { Pandemic } \\
\text { Job } \\
\text { Satisfactio } \\
n \\
\text { Nurses } \\
\text { Occupation } \\
\text { al stress }\end{array}$ & $\begin{array}{l}\text { Nursing } \\
\text { Stress } \\
\text { Scale } \\
\text { Questionna } \\
\text { ire, the } \\
\text { McCloskey/ } \\
\text { Mueller } \\
\text { Satisfaction } \\
\text { Scale and a } \\
\text { questionnai } \\
\text { re } \\
\text { assessing } \\
\text { the COVID- } \\
19 .\end{array}$ & $\begin{array}{l}\text { - } \\
\text { Occupation } \\
\text { al stress } \\
\text { and its } \\
\text { factors. } \\
\text { - } \\
\text { Occupation } \\
\text { al stress. }\end{array}$ & $\begin{array}{l}\text { Physical, psychological and social } \\
\text { stressors are more related to nurses in } \\
\text { COVID-19 triage hospitals than compared } \\
\text { to those working in general hospitals. }\end{array}$ \\
\hline
\end{tabular}




\section{GHM \\ Journal of Global Health \\ and Medicine}

Vol. 6, $\mathrm{N}^{\circ}$ 1, 2022

Copyright (C) 2022, CINCADER.

ISSN 2523-9511

DOI: https://doi.org/10.32829/ghmj.v6i1.158

\begin{tabular}{|c|c|c|c|c|c|}
\hline $\begin{array}{l}\text { Torres, F., } \\
\text { Irigoyen, V., } \\
\text { Moreno, A. } \\
\text { P., Ruilova, } \\
\text { E., Casares, } \\
\text { J. } \\
\text { Mendoza, M. } \\
\text { (2021). }\end{array}$ & $\begin{array}{l}\text { Burnout } \\
\text { syndrome in } \\
\text { Ecuadorian } \\
\text { health } \\
\text { professionals } \\
\text { and } \\
\text { associated } \\
\text { factors in } \\
\text { times of } \\
\text { pandemic. }\end{array}$ & $\begin{array}{l}\text {-Burnout } \\
\text { syndrome. } \\
- \\
\text { Psychologi } \\
\text { cal } \\
\text { exhaustion } \\
-\quad \text { Health } \\
\text { personnel } \\
- \\
\text { Occupation } \\
\text { al stress } \\
\text { - } \\
\text { Profession } \\
\text { al burnout. }\end{array}$ & $\begin{array}{l}\text { Interview } \\
\text { and } \\
\text { questionnai } \\
\text { re } \\
\text {-Maslach } \\
\text { test }\end{array}$ & $\begin{array}{l}\text { Prevalence } \\
\text { of Burnout } \\
\text { Syndrome } \\
\text { Burnout } \\
\text { Syndrome } \\
\text { related to } \\
\text { sociodemog } \\
\text { raphic } \\
\text { factors } \\
\text { Burnout } \\
\text { syndrome } \\
\text { related to } \\
\text { work factors }\end{array}$ & $\begin{array}{l}\text { The prevalence of Burnout Syndrome is } \\
\text { not related to the sex of the professional, } \\
\text { but it is related to age, and there is a } \\
\text { greater probability in young people, } \\
\text { residents and professionals who do not } \\
\text { have a specialty. In addition, having more } \\
\text { children is related to less severity of } \\
\text { Burnout Syndrome. } \\
\text { In the pandemic context, the prevalence of } \\
\text { Burnout Syndrome is high, thus being a } \\
\text { stress factor that has consequences on } \\
\text { patient safety and legal implications for the } \\
\text { professional when committing an error in } \\
\text { their care. }\end{array}$ \\
\hline $\begin{array}{l}\text { Carrasco, O., } \\
\text { Castillo, E., } \\
\text { Salas, R., \& } \\
\text { Reyes, } \\
\text { (2020). }\end{array}$ & $\begin{array}{l}\text { Job stressors } \\
\text { and } \\
\text { satisfaction in } \\
\text { Peruvian } \\
\text { nurses during } \\
\text { the COVID - } \\
19 \text { pandemic. }\end{array}$ & $\begin{array}{l}\text { Job stress } \\
\text { job } \\
\text { satisfaction } \\
\text { Role of the } \\
\text { nurse }\end{array}$ & $\begin{array}{l}\text { Cuestionari } \\
\text { o Nursing } \\
\text { Stress } \\
\text { Scale }\end{array}$ & $\begin{array}{l}\text { Level of job } \\
\text { stressors } \\
\text { Level of job } \\
\text { satisfaction }\end{array}$ & $\begin{array}{l}\text { The environmental factor (hospital } \\
\text { characteristics, budget, infrastructure and } \\
\text { equipment) and the personal factor } \\
\text { (interrelationship with colleagues, } \\
\text { recognition criteria and preparation) with } \\
\text { respect to personal satisfaction showed a } \\
\text { significant direct relationship. } \\
\text { The environmental and personal factors in } \\
\text { Peruvian nurses working in direct patient } \\
\text { care in the COVID-19 context were } \\
\text { associated with job satisfaction. }\end{array}$ \\
\hline $\begin{array}{l}\text { Chávez, L., } \\
\text { Marcet, G., } \\
\text { Ramírez, E., } \\
\text { Acosta, L. \& } \\
\text { Samudio M. } \\
\text { (2020). }\end{array}$ & $\begin{array}{l}\text { Mental health } \\
\text { of medical } \\
\text { and nursing } \\
\text { staff at the } \\
\text { National } \\
\text { Institute of } \\
\text { Respiratory } \\
\text { and } \\
\text { Environment } \\
\text { al Diseases } \\
\text { during the } \\
\text { COVID-19 } \\
\text { pandemic } \\
\text { quarantine. }\end{array}$ & $\begin{array}{l}\text { Anxiety } \\
\text { Depression } \\
\text { Burnout } \\
\text { Syndrome }\end{array}$ & $\begin{array}{l}\text { The first } \\
\text { questionnai } \\
\text { re included } \\
13 \\
\text { questions } \\
\text { on demographi } \\
\text { dem and } \\
\text { c occupation } \\
\text { al data. } \\
\text { The second } \\
\text { questionnai } \\
\text { re was the } \\
\text { GAD-7 (7- } \\
\text { item } \\
\text { Generalize } \\
\text { d Anxiety } \\
\text { Disorder). } \\
\text { The third } \\
\text { questionnai } \\
\text { re was the } \\
\text { PHQ-9 (9- } \\
\text { item Patient }\end{array}$ & $\begin{array}{l}\text { Risk factors } \\
\text { for } \\
\text { developing } \\
\text { anxiety, } \\
\text { depression } \\
\text { and burnout } \\
\text { syndrome. } \\
\text { Association } \\
\text { of anxiety } \\
\text { with burnout } \\
\text { and } \\
\text { depression } \\
\text { in health } \\
\text { personnel. }\end{array}$ & $\begin{array}{l}\text { The workload of } 12 \text { hours or more was } \\
\text { associated with the risk of developing } \\
\text { anxiety, depression and Burnout } \\
\text { syndrome. } \\
\text { The male sex presented a higher risk of } \\
\text { developing anxiety } \\
\text { Intensive care and surgical personnel had } \\
\text { a significantly higher risk of developing } \\
\text { anxiety and depression. } \\
\text { Health personnel who presented a higher } \\
\text { risk of developing anxiety had a higher risk } \\
\text { of developing depression and burnout. }\end{array}$ \\
\hline
\end{tabular}




\section{GHM

Vol. 6, $\mathrm{N}^{\circ}$ 1, 2022

Copyright @ 2022, CINCADER.

ISSN 2523-9511

DOI: https://doi.org/10.32829/ghmj.v6i1.158

\begin{tabular}{|c|c|c|c|c|c|}
\hline & & & $\begin{array}{l}\text { health } \\
\text { questionnai } \\
\text { re). }\end{array}$ & & \\
\hline $\begin{array}{lr}\text { Silva, } & \text { V., } \\
\text { Steil, A., \& } \\
\text { Teixeira } & \text { de } \\
\text { Gois, } & \text { A. } \\
\text { (2021). } & \end{array}$ & $\begin{array}{l}\text { COVID } 19 \\
\text { pandemic in } \\
\text { Sao Paulo: a } \\
\text { quantitative } \\
\text { study on } \\
\text { clinical } \\
\text { practice and } \\
\text { mental health } \\
\text { among } \\
\text { medical } \\
\text { residency } \\
\text { specialties. }\end{array}$ & $\begin{array}{l}\text { - Covid } 19 \\
\text { - Internship } \\
\text { and } \\
\text { internship } \\
\text { - Health }\end{array}$ & $\begin{array}{l}\text { Survey in } \\
\text { line with the } \\
\text { parameters } \\
\text { of } \\
\text { Strengtheni } \\
\text { ng the } \\
\text { Reporting } \\
\text { of } \\
\text { Observatio } \\
\text { nal Studies } \\
\text { in } \\
\text { Epidemiolo } \\
\text { gy. }\end{array}$ & $\begin{array}{l}\text { Clinical } \\
\text { specialties } \\
\text { Mental } \\
\text { Health }\end{array}$ & $\begin{array}{l}\text { Depressive symptoms were the most } \\
\text { frequent followed by symptoms of anxiety } \\
\text { and burnout among residents because of } \\
\text { ineffective personal protective equipment, } \\
\text { in addition to the concern of being infected } \\
\text { by covid and transmitting it to their families. } \\
\text { Symptoms of anxiety and burnout were } \\
\text { also observed among clinical specialties. } \\
\text { Residents in clinical specialties are at } \\
\text { increased risk for anxiety, depression, and } \\
\text { burnout. Symptoms of anxiety and } \\
\text { depression have worsened during the } \\
\text { COVID-19 pandemic. }\end{array}$ \\
\hline $\begin{array}{lr}\text { Delgado J., } & \text { Jontemayor- } \\
\text { Morza R., } & \text { Rorilla- } \\
\text { Padivas, } & \text { G., } \\
\text { Rivasco- } & \\
\text { Franco } & \\
\text { Villareal } & \text { H. \& } \\
\text { Islas, } & \text { J. } \\
\text { (2020). } & \end{array}$ & $\begin{array}{l}\text { Prevalence } \\
\text { of stress in } \\
\text { health care } \\
\text { professionals } \\
\text { during the } \\
\text { COVID-19 } \\
\text { pandemic in } \\
\text { northeastern } \\
\text { Mexico: a } \\
\text { rapid, remote } \\
\text { survey } \\
\text { assessment } \\
\text { using an } \\
\text { adapted } \\
\text { cOVID-19 } \\
\text { stress scale. }\end{array}$ & $\begin{array}{l}\text { COVID-19 } \\
\text { Mexico; } \\
\text { COVID-19 } \\
\text { stress } \\
\text { scales; } \\
\text { stress in } \\
\text { health } \\
\text { profession } \\
\text { als. }\end{array}$ & $\begin{array}{l}\text { Questionna } \\
\text { ire adapted } \\
\text { with the } \\
\text { COVID-19 } \\
\text { stress } \\
\text { scales } \\
\text { (CSS) } \\
\text { according } \\
\text { to the 36- } \\
\text { item } \\
\text { questionnai } \\
\text { re } \\
\text { developed } \\
\text { by Taylor et } \\
\text { al. } \\
\text { CSS } \\
\text { developed } \\
\text { by Taylor et } \\
\text { al., which is } \\
\text { used to } \\
\text { assess } \\
\text { symptoms } \\
\text { of stress } \\
\text { and anxiety } \\
\text { in daily life. }\end{array}$ & $\begin{array}{l}\text { Structure } \\
\text { and } \\
\text { adaptation } \\
\text { of the stress } \\
\text { scale. } \\
\text { Frequency } \\
\text { of stress } \\
\text { related to } \\
\text { COVID }\end{array}$ & $\begin{array}{l}\text { Normal stress levels have increased (mild } \\
\text { to moderate). Additionally, it was } \\
\text { determined that fear of an asymptomatic } \\
\text { patient remains a concern because of the } \\
\text { silent spread of the virus. }\end{array}$ \\
\hline $\begin{array}{l}\text { Munawar, } \text { K. } \\
\& \text { Riaz., F. } \\
(2021) .\end{array}$ & $\begin{array}{l}\text { Exploring the } \\
\text { stress coping } \\
\text { strategies of } \\
\text { frontline } \\
\text { health care } \\
\text { workers } \\
\text { treating } \\
\text { Covid-19 in }\end{array}$ & $\begin{array}{l}\text { Coronaviru } \\
\text { S disease } \\
2019 \\
\text { Epidemic } \\
\text { outbreak; } \\
\text { Frontline } \\
\text { health care } \\
\text { workers }\end{array}$ & $\begin{array}{l}\text { Semi- } \\
\text { structured } \\
\text { interviews } \\
\text { (face-to- } \\
\text { face and by } \\
\text { phone). }\end{array}$ & $\begin{array}{l}\text { Stress } \\
\text { coping } \\
\text { mechanism } \\
\text { s } \\
\text { Altruism } \\
\text { and } \\
\text { empathy }\end{array}$ & $\begin{array}{l}\text { Stress coping includes limiting media } \\
\text { exposure, limited sharing of Covid- } 19 \text { duty } \\
\text { details, religious coping, only other } \\
\text { emergency approach, altruism, and the } \\
\text { second main theme of Challenges includes } \\
\text { psychological response and non- } \\
\text { compliance of the public. / denial by } \\
\text { religious scholar. media is the main source }\end{array}$ \\
\hline
\end{tabular}


Vol. 6, $\mathrm{N}^{\circ}$ 1, 2022

Copyright (c) 2022, CINCADER.

DOI: https://doi.org/10.32829/ghmj.v6i1.158

\begin{tabular}{|c|c|c|c|c|c|}
\hline & $\begin{array}{l}\text { Pakistan: a } \\
\text { qualitative } \\
\text { investigation. }\end{array}$ & & & $\begin{array}{l}\text { Challenges } \\
\text { and } \\
\text { problems }\end{array}$ & $\begin{array}{l}\text { of stress and anxiety among the public. } \\
\text { Religious coping, as well as their passion } \\
\text { to serve humanity and the country, were } \\
\text { the commonly employed coping strategies }\end{array}$ \\
\hline $\begin{array}{l}\text { Şanlıtürk, D. } \\
(2021) .\end{array}$ & $\begin{array}{l}\text { Perception } \\
\text { and sources } \\
\text { of } \\
\text { occupational } \\
\text { stress in } \\
\text { intensive } \\
\text { care nurses } \\
\text { during the } \\
\text { COVID-19 } \\
\text { pandemic. }\end{array}$ & $\begin{array}{l}\text { COVID- } \\
19 ; \\
\text { Intensive } \\
\text { care; } \\
\text { Nurses; } \\
\text { Job stress. }\end{array}$ & $\begin{array}{l}\text { The } \\
\text { Perceived } \\
\text { Stress } \\
\text { Scale-14. }\end{array}$ & $\begin{array}{l}\text { Descriptive } \\
\text { characteristi } \\
\text { cs Stress } \\
\text { factors } \\
\text { Relationshi } \\
\text { p between } \\
\text { descriptive } \\
\text { characteristi } \\
\text { cs of the } \\
\text { participants } \\
\text { and the } \\
\text { level of job } \\
\text { stress }\end{array}$ & $\begin{array}{l}\text { The percentage of nurses with moderate } \\
\text { level of occupational stress was } 62 \% \text {. } \\
\text { High working hours and nurse: patient } \\
\text { ratio, heavy workload and failure to treat } \\
\text { patients were the main occupational } \\
\text { stressors. The level of occupational stress } \\
\text { was affected by gender, number of } \\
\text { children, years of experience in intensive } \\
\text { care, and type of work shift } \\
\text { Intensive care nurses in Turkey } \\
\text { experienced moderate stress during the } \\
\text { COVID-19 pandemic. }\end{array}$ \\
\hline $\begin{array}{l}\text { Kumar, } \\
\text { Fonseca, } \\
\text { Verma, } \\
\text { Kumar, } \\
\text { (2021). }\end{array}$ & $\begin{array}{l}\text { Assessment } \\
\text { of } \\
\text { occupational } \\
\text { stress among } \\
\text { nuclear } \\
\text { medicine } \\
\text { technical } \\
\text { professionals } \\
\text { in India. }\end{array}$ & $\begin{array}{l}\text { Occupation } \\
\text { al stress; } \\
\text { Occupation } \\
\text { al stress; } \\
\text { Nuclear } \\
\text { medicine; } \\
\text { Health } \\
\text { profession } \\
\text { als }\end{array}$ & $\begin{array}{l}\text { Nuclear } \\
\text { Medicine } \\
\text { Occupation } \\
\text { al Stress } \\
\text { Questionna } \\
\text { ire } \\
\text { (NMOSQ) } \\
\text { and SPSS } \\
\text { system. }\end{array}$ & $\begin{array}{l}\text { Occupation } \\
\text { al stress } \\
\text { and its } \\
\text { consequenc } \\
\text { es } \\
\text { Occupation } \\
\text { al stress }\end{array}$ & $\begin{array}{l}\text { Factors that contribute to work-related } \\
\text { stress and what impact they have on the } \\
\text { professional environment. }\end{array}$ \\
\hline $\begin{array}{l}\text { Prasad, K., } \\
\text { McLoughlin, } \\
\text { C., Stillman, } \\
\text { M., Poplau, } \\
\text { S., Goelz, E., } \\
\text { Taylor, S., } \\
\text { Nankivil, N., } \\
\text { Brown, R., } \\
\text { Linzer, M., } \\
\text { Cappelucci, } \\
\text { K., } \\
\text { Barbouche, } \\
\begin{array}{l}\text { M., \& Sinsky, } \\
\text { C. A. (2021). }\end{array}\end{array}$ & $\begin{array}{l}\text { Prevalence } \\
\text { and } \\
\text { correlates of } \\
\text { stress and } \\
\text { burnout } \\
\text { among U.S. } \\
\text { health care } \\
\text { workers } \\
\text { during the } \\
\text { COVID-19 } \\
\text { pandemic: a } \\
\text { national } \\
\text { cross- } \\
\text { sectional } \\
\text { survey study. }\end{array}$ & $\begin{array}{l}\text { COVID-19 } \\
\text { Occupation } \\
\text { al Stress } \\
\text { Burnout } \\
\text { Nursing } \\
\text { Allied } \\
\text { health } \\
\text { profession } \\
\text { als } \\
\text { Mental } \\
\text { health }\end{array}$ & $\begin{array}{l}\text { Survey } \\
\text { "Facing the } \\
\text { COVID". }\end{array}$ & $\begin{array}{l}\text { Stressors } \\
\text { and } \\
\text { mitigators } \\
\text { by health } \\
\text { care } \\
\text { worker's } \\
\text { role } \\
\text { Occupation } \\
\text { al variability }\end{array}$ & $\begin{array}{l}\text { Fear, anxiety/depression, and workload } \\
\text { showed strong associations with stress, } \\
\text { while feeling valued was associated with } \\
\text { less stress } \\
\text { Feeling valued was correlated with lower } \\
\text { stress and was associated with lower } \\
\text { burnout, lower workload } \\
\text { Approximately } 50 \% \text { of workers did not feel } \\
\text { valued } \\
\text { Higher stress and burnout were found in } \\
\text { several health professions, including } \\
\text { nursing assistants, medical assistants, } \\
\text { homemakers, and social workers, as well } \\
\text { as in female workers and racially minority } \\
\text { workers. } \\
\text { Fear of exposure or transmission, self- } \\
\text { reported anxiety/depression, and work } \\
\text { overload were associated with stress and } \\
\text { burnout, whereas feeling valued was } \\
\text { associated with better outcomes. }\end{array}$ \\
\hline
\end{tabular}




\section{GHM \\ Journal of Global Health and Medicine}

Vol. 6, $\mathrm{N}^{\circ} 1,2022$

\section{Discusions}

In the present systematic review, 19 articles were found in the following databases: $36.8 \%$ in Pubmed, $31.6 \%$ in Scielo, $21.1 \%$ in Sciencedirect and finally $10.5 \%$ in Lilacs. In relation to the countries identified we have Brazil, India, Turkey, Italy and Ecuador each with $10.53 \%$ and with $5.26 \%$ we have Peru, Argentina, Mexico, United States, Pakistan, Taiwan, China, Egypt and Paraguay with respect to the languages were 4 Spanish, 1 Portuguese and 14 in English, the methodology used was mostly quantitative with $94.74 \%$ and Qualitative $5.26 \%$.

On the other hand, all authors agree in referring that COVID-19 is a major public health challenge worldwide and the fight against COVID-19 have a heavier workload and a higher level of responsibility. Working hours per day, years of service, number of night shifts per week, and level of academic qualification were the main factors influencing work stress among health care professionals in the care area. Next, of the findings found in work stress of health professionals in times of pandemic were:

\section{Factores Desencadenantes del Estrés Laboral:}

Among them we have sociodemographic factors such as age; according to (Torres et al., 2021), et al, refer that young age has a higher prevalence in developing burnout syndrome. Regarding Kumar et al. (2020), Rodrigues et al. (2020) and Tengilimoğlu et al. (2021), several authors agree that the highest levels of stress were found of female gender (Chávez et al., 2020; Kumar et al., 2021 ) indicate that the male gender presented a higher risk of developing anxiety, fatigue and low mood compared to the female gender. In marital status according to (Kuo et al., 2020), they refer that most of them are married women, and on the contrary (Magnavita et al., 2020) express that work stress was evidenced in the population of single women without children, who fear for their own life and infect those who live with them at home. In addition to the number of children; (Şanlıtürk, 2021; Zhan et al., 2020), refer that work stress was increased by the number of children women have, in addition, fear for contagion to their family.

Another triggering factor is the one that occurs in the work environment, thus Tengilimoğlu et al. (2021) and Magnavita et al. (2020), state that the highest levels of stress come from critical areas, emergency, anesthesiology and intensive care, presenting considerably higher risk of presenting anxiety and depression. In addition, refers that nuclear medicine technicians have a high level of occupational biological risk and are more predisposed to occupational stress. In the case of time of service and lack of work experience according to Franco et al. (2020), states that personnel working less than 3 years have evidenced a greater increase in occupational stress, on the contrary Kuo et al. (2020), and Said et al. (2020), states that professionals with extensive work experience working in hospitals, have evidenced a high risk of developing occupational stress. On the other hand, in relation to Work Overload, the authors Kuo et al. (2020), indicate that work overload influences the occurrence of stress in healthcare professionals. On the other hand, it is worth mentioning that one of the stressors for hospital staff is the lack of personal protective equipment.

According to Kuo et al. (2020), he mentions that for better containment of work overload he suggests installing differentiated triage at the entrances and exits of each workplace, in addition, medical tents, special areas for the reception of patients in emergency and that would lead to obtain more infrastructure, supplies and health personnel.

So, the purpose is not to end stress in the person, but to obtain an adequate management in daily life. This is due to the fact that the stress response of the modern human being is frequently inappropriate due to its level of intensity and the situations he/she faces (Rodrigues et al., 2020). Protective factors for occupational stress in health professionals are related to free time dedicated to physical and spiritual activities and limiting prolonged exposure to the media, news and social networks as they can create panic in the population with unreliable sources related to COVID19. 


\section{GHM \\ Journal of Global Health and Medicine}

Vol. 6, $\mathrm{N}^{\circ} 1,2022$

Copyright @ 2022, CINCADER.

ISSN 2523-9511

DOI: https://doi.org/10.32829/ghmj.v6i1.158

Additionally, faith-based practices and belief systems are considered to play an important role in addressing the pandemic, which helped to significantly alleviate occupational stress. It should be noted that the development of care and spiritual growth of health professionals should be encouraged, without neglecting the provision of humanized care through empathy and compassion that characterizes our noble profession, This is why it is important to highlight the spiritual need of health professionals that many times with the passage of time is lost becoming mechanical people absorbed by the routine and even more in the current situation of increased work stress, therefore, having moments of quiet reflection, recreational spaces where to take advantage of free time are strategies to cope with the work stress that we are going through. Being aware that providing holistic care is immersed in spirituality in the practice of nursing, little attention has been paid to it since nursing has focused on technology and scientific progress, neglecting this very important part. (Galvis \& Pérez, 2013).

Additionally, there is a need to strengthen professional knowledge in times of pandemic, participate in various trainings that provide knowledge about COVID-19, disseminate that same knowledge and inform about the epidemic to their patients, will help to reduce work stress (Zhan et al., 2020).

Preventive and/or occupational policies against work-related stress.

The authors of the different articles that were reviewed for the elaboration of this systematic review make mention of recommendations in the prevention of occupational stress such as prevention and coping strategies by making supportive interventions for mental health and recommend that workplaces should perform a permanent psychological evaluation and monitoring (Ramachandran et al., 2020; Zhan et al., 2020; Kuo et al., 2020; Torres et al., 2021; Chávez et al., 2020; Silva et al., 2021) Furthermore, they refer that managers or leaders of the different health professions should promote active and effective measures thus reducing the impact of work stress (Zhan et al., 2020; Tengilimoğlu et al., 2021) measures aimed at the optimization of human resources, attendance planning, incentive management, hierarchical training, group management and optimization of shift scheduling 3.

On the other hand, it is suggested to carry out more comparative studies of the levels of work stress among the different health professionals according to their specialties, which so far are scarce, to carry out structural reforms and interventions related to peer support programs and thus help preserve the psychological well-being of health workers in the face of the crisis (Silva et al., 2021; Prasad et al., 2021).

In this systematic review work stress is a latent problem that affects the physical, emotional and psychological state, where some authors recommend balancing the work environment by avoiding work overload of professionals, developed psychological coping strategies, assessment, monitoring and continuous intervention of health personnel to reduce work stress (Kuo et al., 2020; Said \& El-Shafei, 2020; Ramachandran et al., 2021) Work overload could cause burnout syndrome in workers, with implications for patient safety due to the lack of time to perform care according to the scheduled shift, in addition to human errors that would have legal consequences for the professional and the institution where he/she works.

\section{Conclusions}

The high levels of occupational stress in health professionals according to authors of the systematic review coincide in psychological damage such as anxiety, burnout syndrome and depression cannot be overlooked decision making by the authorities of each work center to implement coping strategies in the human resource that is on the front line to date battling COVID- 


\section{GHM \\ Journal of Global Health and Medicine}

Vol. 6, No 1, 2022

19 , it is thus necessary to coordinate preventive activities to cope with stress require the support of the team or department of psychology and psychiatry to mitigate the impact of mental health of workers in order not to suffer the risk of psychiatric illness, in addition, patients are no strangers to occupational stress symptoms of health workers especially in nurses, resulting in dissatisfaction of the services offered by health personnel for recovery and rehabilitation. Likewise, it is necessary to apply techniques, technological tools and continuous psychological evaluations to measure stress levels, to give effective psychological interventions and reduce the impact of occupational health of health professionals.

\section{References}

Carrasco, O., Castillo, E., Salas, R., \& Reyes, C. 2020. Estresores laborales y satisfacción en enfermeras peruanas durante la pandemia de COVID - 19. Scielo Preprints, 1(1), 1-14. https://doi.org/https://doi.org/10.1590/SciELOPreprints. 1468

CDC, Centers for Disease Control and Prevention. 2021. Employees: How to Cope with Work Stress and Build Resilience During the COVID-19 Pandemic. https://espanol.cdc.gov/coronavirus/2019-ncov/community/mental-health-non-healthcare.html

Cirami, L., Córdoba, E., \& Ferrari, L. 2020. Estrategias de afrontamiento del estrés laboral en trabajadores de la salud y reflexiones acerca de las transformaciones organizacionales a partir de la pandemia de COVID-19. Subjetividad y Procesos Cognitivos, 24(2), 118132(2020)., 24 ,

118-132. http://dspace.uces.edu.ar:8180/xmlui/bitstream/handle/123456789/5708/Cirami_otros_Estrategias_ afrontamiento.pdf?sequence $=1$

Chávez, L., Marcet, G., Ramírez, E., Acosta, L. \& Samudio M. 2020. Salud mental del personal médico y enfermería del Instituto Nacional de Enfermedades Respiratorias y del Ambiente durante la cuarentena por la pandemia COVID-19, Paraguay 2020. http://scielo.iics.una.py/scielo.php?script=sci_arttext\&pid=S2307-33492021000100074

De los Santos, J., \& Labrague, L. 2020. Impact of COVID-19 on the Psychological Well-Being and Turnover Intentions of Frontline Nurses in the Community: A Cross-Sectional Study in the Philippines. https://doi.org/10.1101/2020.08.05.20167411

Delgado J., Montemayor-Garza R., Padilla-Rivas, G., Franco- Villareal H. \& Islas, J. 2020. Prevalence of Stress in Healthcare Professionals during the COVID-19 Pandemic in Northeast Mexico: A Remote, Fast Survey Evaluation, Using an Adapted COVID-19 Stress Scales. International Journal of Environmental Research and Public Health, 17(20), 1-12. https://pubmed.ncbi.nlm.nih.gov/33086744/

Ferreira, V., Yuri, T., Pereira A. 2020. Difficulties and fears of nurses facing the COVID-19 pandemic in Brazil. http://scielo.sld.cu/pdf/hmc/v20n2/1727-8120-hmc-20-02-312.pdf

Franco, J. A. F., \& Levi, P. de los Á. 2020. Feelings, Stress, and Adaptation Strategies of Nurses against COVID-19 in Guayaquil. Investigación y Educación En Enfermería, 38(3), 1-14. https://doi.org/10.17533/UDEA.IEE.V38N3E07

Galvis, M., \& Pérez, B. 2013. Revisión de la literatura sobre el concepto "espiritualidad" aplicado a la práctica de enfermería - aladefe. Enfermeria21. Aladefe. https://www.enfermeria21.com/revistas/aladefe/articulo/82/revision-de-la-literatura-sobre-elconcepto-espiritualidad-aplicado-a-la-practica-de-enfermeria/

Informes de situación de la enfermedad por coronavirus (COVID-19). 2021. https://www.who.int/emergencies/diseases/novel-coronavirus-2019/situation-reports

Jianbo I., Simeng M. Ying W., Zhongxiang C. 2020. Factors Associated with Mental Health Outcomes Among Health Care Workers Exposed to Coronavirus Disease 2019. JAMA Network Open, 3(3). https://doi.org/10.1001/JAMANETWORKOPEN.2020.3976

Kumar, A., \& Nair, R. 2020. Stress Levels of Indian Endodontists during COVID-19 Pandemic Niveles de estrés de endodoncistas de la India durante la pandemia COVID-19. Revista Cubana de Estomatología. http://www.scielo.sld.cu/pdf/est/v57n3/1561-297X-est-57-03e3445.pdf 


\section{GHM \\ Journal of Global Health and Medicine}

Vol. 6, $\mathrm{N}^{\circ}$ 1, 2022

Kumar, S., Fonseca, K., Verma, A., \& Kumar, R. 2021. Assessment of the occupational stress among nuclear medicine technical professionals in India. Clinical Epidemiology and Global Health, 11, 100786. https://doi.org/10.1016/J.CEGH.2021.100786

Kuo, F.L., Yang, P-H., Hsu H-T., Su C-Y., Chen, C-H., Yeh, Y-J., Wu, Y-H. \& Chen, L-Ch. 2020. Survey on perceived work stress and its influencing factors among hospital staff during the COVID-19 pandemic in Taiwan. Kaohsiung J Med Sci. 2020; 36:944-952. https://pubmed.ncbi.nlm.nih.gov/32815248/

Lozano-Vargas, A. 2020. Impacto de la epidemia del Coronavirus (COVID-19) en la salud mental del personal de salud y en la población general de China. Revista de Neuro-Psiquiatría. https://doi.org/10.20453/RNP.V8311.3687

Magnavita, N., Soave, P.M., Ricciardi, W. \& Antonelli, M. 2020. Occupational Stress and Mental Health among Anesthetists during the COVID-19 Pandemic. Int. J. Environ. Res. Public Health. https://doi.org/10.3390/ijerph17218245

Marquina-Lujan, R., \& Adriazola, R. 2020. Autopercepción del estrés del personal de salud en primera línea de atención de pacientes con COVID-19 en Lima Metropolitana, Perú. Revista de La Escuela de Enfermería. https://revistas.usat.edu.pe/index.php/cietna/article/view/391

Monterrosa-Castro, Á., Dávila-Ruiz, R., Mejía-Mantilla, A., Contreras-Saldarriaga, J., MercadoLara, M., Flores-Monterroso, Ch. 2020. Estrés laboral, ansiedad y miedo al COVID-19 en médicos generales

colombianos. https://revistas.unab.edu.co/index.php/medunab/article/view/3890/3280

Munawar, K. \& Riaz., F. 2021. Exploring stress coping strategies of frontline emergency health workers dealing Covid-19 in Pakistán: A qualitative inquiry. American Journal of Infection Control, 49(3), 286-292. https://doi.org/10.1016/J.AJIC.2020.06.214

OIT. 2016. Estrés Laboral. from https://www.ilo.org/wcmsp5/groups/public/---americas/---rolima/documents/genericdocument/wcms_475146.pdf

Oliva-Yarlequé, Y., \& Chávarry-Ysla, PR. 2021. Impacto emocional en el profesional de enfermeria durante la pandemia. Revista Científica de Enfermería. Latindex. https://revista.cep.org.pe/index.php/RECIEN/article/view/85/95

Orrù, G., Marzetti, F., Conversano, C., Vagheggini, G., Miccoli, M., Ciacchini, R., Panait, E., \& Gemignani, A. 2021. Secondary Traumatic Stress and Burnout in Healthcare Workers during COVID-19 Outbreak. Int. J. Environ. Res. Public Health, 18, 337. https://doi.org/10.3390/ijerph18010337

Ozamiz-Etxebarria, N., Dosil-Santamaria, M., Picaza-Gorrochategui, M., \& Idoiaga-Mondragon, N. 2020. Niveles de estrés, ansiedad y depresión en la primera fase del brote del COVID19 en una muestra recogida en el norte de España. https://doi.org/10.1590/0102$311 \times 00054020$

Pan American Health Organization, 2019. The WHO characterizes COVID-19 as a pandemic. United States of America. https://www3.paho.org/hq/index.php?option=com_co ntent\&view=article\&id=15756: who-characterizescovid-19-as-apandemic\&ltemid $=1926 \&$ lang $=$ en

Prasad, K., McLoughlin, C., Stillman, M., Poplau, S., Goelz, E., Taylor, S., Nankivil, N., Brown, R., Linzer, M., Cappelucci, K., Barbouche, M., \& Sinsky, C. A. 2021. Prevalence and correlates of stress and burnout among U.S. healthcare workers during the COVID-19 pandemic: A national cross-sectional survey study. EClinicalMedicine, 35, 100879. https://www.sciencedirect.com/science/article/pii/S2589537021001590

Ramachandran, A., Savrimalai, C., Kattula, D., Thavarajah, R., \& Arunachalam, A. 2020. Stress Levels of Indian Endodontists during COVID-19 Pandemic. Revista Cubana de Estomatología. $75072020000300002 \& \operatorname{lng}=\mathrm{es} \&$ tIng $=$.

Rodrigues, L., Coelho de Oliveira, L., \& França Dourado, M. 2020. Empatia, depressão, ansiedade e estresse em Profissionais de Saúde Brasileiros. Ciencias Psicológicas, 14(2). https://doi.org/10.22235/CP.V14I2.2215 
Vol. 6, $\mathrm{N}^{\circ} 1,2022$

Said, R. \& El-Shafei, D. 2020. Occupational stress, job satisfaction, and intent to leave: nurses working on front lines during COVID-19 pandemic in Zagazig City, Egypt. Environ Sci Pollut Res 28, 8791-8801. https://doi.org/10.1007/s11356-020-11235

Şanlıtürk, D. 2021. Perceived and sources of occupational stress in intensive care nurses during the COVID-19 pandemic. Intensive and Critical Care Nursing, 103107. https://doi.org/10.1016/J.ICCN.2021.103107

Silva, V., Steil, A., \& Teixeira de Gois, A. 2021. COVID-19 pandemic in São Paulo: a quantitative study on clinical practice and mental health among medical residency specialties. Sao Paulo Med J, 139(5), 489. https://pubmed.ncbi.nlm.nih.gov/34287511/

Tengilimoğlu, T., Aysu, Z., Nurperihan, T., Oguz, I., \& Tengilimoglu, O. 2021. Impacts of COVID19 pandemic period on depression, anxiety and stress levels of the healthcare employees in Turkey. Legal Medicine (48). https://doi.org/10.1016/J.LEGALMED.2020.101811

Tipos de Estrés Laboral | Efectos y Consecuencias - Grupo IOE. 2018. Business School. https://www.grupoioe.es/tipos-de-estres-laboral/

Torres, F., Irigoyen, V., Moreno, A. P., Ruilova, E., Casares, J. \& Mendoza, M. 2021. Síndrome de Burnout en profesionales de la salud del Ecuador y factores asociados en tiempos de pandemia. Rev. Virtual Soc. Parag. Med. Int. Marzo, 8(1). https://doi.org/10.18004/rvspmi/2312-3893/2021.08.01.126

William, W., Jeffrey P., Seema, R., Murtuza, G., Nisanth, M., Harshit, M., Roshan, M. 2020. Prevalencia y predictores de estrés, ansiedad y depresión entre los trabajadores de la salud que manejan la pandemia de COVID-19 en la India: un estudio observacional a nivel nacional. https://doi.org/10.1177/0253717620933992

World Health Organization, 2019. La OMS caracteriza al COVID-19 como una pandemia. Oficina Regional para las Américas de La Organización Mundial de La Salud. Estados Unidos de América. https://www.who.int/es/emergencies/diseases/novel-coronavirus-2019

Zhan, Y., Shuangma, Xiangdongjian, Yingjuan, C. \& Xiangqiao Z. 2020, The Current Situation and Influencing Factors of Job Stress Among Frontline Nurses Assisting in Wuhan in Fighting COVID-19. https://pubmed.ncbi.nlm.nih.gov/33194981/ 